\title{
CYTOMORPHOLOGICAL AND BIOCHEMICAL CORRELATION IN THYROIDITIS
}

\author{
Mani Krishna ${ }^{1}$ Manju $^{2}$ \\ ${ }^{1}$ Associate Professor, Department of Pathology, UP Rural Institute of Medical Sciences and Research, Saifai, Etawah, Uttar Pradesh. \\ ${ }^{2}$ Consultant, Zonal Hospital, Dharamshala, Himachal Pradesh.
}

\begin{abstract}
Hashimoto's thyroiditis is an autoimmune chronic inflammatory disease of the thyroid gland. It is the second most common thyroid lesion diagnosed by cytology, after goiter.

MATERIAL AND METHOD: The Study was conducted in the department of pathology. All aspiration were done by cytopathologists to ensure representative sampling.Using sterile precautions FNAC was performed using nonaspiration or aspiration techniques by 23 G needle with $10 \mathrm{ml}$ syringe. The smears were either air dried or alcohol fixed (95\%). Air dried smears were stained by the Gimsa stain and alcohol fixed by Hematoxiline and eosin.

RESULT: We included 75 cases of thyroiditis. 4 cases were male and 71 were female with female to male ratio of 17.75:1. The age ranged from 8 to 65years with a median age of 36.5 years. 75 csaes of thyroiditis have been evaluated on the basis of cytomorphological criteria, Biochemical and clinical findings of patients.
\end{abstract}

CONCLUSION: FNAC is a safe, reliable, cost effective and time saving method in the diagnosis of thyroiditis.

KEYWORDS: Thyroid, Biochemical Profile, Thyroiditis.

HOW TO CITE THIS ARTICLE: Mani Krishna, Manju. "Cytomorphological and Biochemical Correlation in Thyroiditis”. Journal of Evolution of Medical and Dental Sciences 2015; Vol. 4, Issue 90, November 09; Page: 15527-15529,

DOI: $10.14260 /$ jemds/2015/2223.

INTRODUCTION: Hashimoto's thyroiditis is an autoimmune chronic inflammatory disease of the thyroid gland. The first report of chronic thyroiditis, struma lymphomatosa was described by Hakaru Hashimoto in 1912, which bears his name. ${ }^{1}$ Hashimoto's thyroiditis also known as chronic lymphocytic thyroiditis has a prevalence rate of $1-4 \%$ and incidence of 3-6/10000 population per year. ${ }^{2}$ It is the second most common thyroid lesion diagnosed by cytology, after endemic goiter. ${ }^{3}$ This disorder is more common in women than in men. Patients usually present with a diffuse enlargement of the thyroid gland or less frequently with one or two prominent nodules. ${ }^{3}$ In the usual clinical course, hypothyroidism develops gradually. ${ }^{2}$ Incidence of Hashimoto's thyroiditis seems to be increasing in the recent times. ${ }^{4,5}$

MATERIAL AND METHOD: The Study was conducted in the department of pathology at Dr Rajendra Prasad Government Medical College Kangra Himachal Pradesh. Clinical details including the age and sex distribution, nodular presentation were analyzed.The correlation between the cytological features, and the biochemical findings were also studied. Prior to aspiration, a physical examination was carried out to note the mobility of the thyroid swelling during swallowing.

All aspiration were done by cytopathologists to ensure representative sampling.Using sterile precautions FNAC was performed using nonaspiration or aspiration techniques by $23 \mathrm{G}$ needle with $10 \mathrm{ml}$ syringe.

Financial or Other, Competing Interest: None.

Submission 13-10-2015, Peer Review 14-10-2015,

Acceptance 26-10-2015, Published 07-11-2015.

Corresponding Author:

Dr. Mani Krishna,

Department of Pathology,

UP Rural Institute of Medical Sciences and Research,

Saifai, Etawah, Uttar Pradesh.

E-mail: drmanikrishna@gmail.com

DOI: $10.14260 /$ jemds/2015/2223.
The smears were either air dried or alcohol fixed (95\%). Air dried smears were stained by the Gimsa stain and alcohol fixed by Hematoxiline and eosin. The diagnosis of Hashimoto's thyroiditis was confirmed by finding lymphocytic infiltrates in clusters of follicular epithelial cell, Hurthle cell changes and increased number of lymphocytes in the background and of colloid goiter by the presence of cohesive monolayer sheets or poorly cohesive clusters of follicular epithelial cells, bare nuclei, macrophages and abundant colloid, multinucleated giant cells, epithelioid cell clusters and anisonucleosis.The present study was designed to asses the usefulness of FNAC to diagnose various types of thyroiditis and to study correlation of thyroid profile.

RESULT: We included 75 cases of thyroiditis. 4 cases were male and 71 were female with female to male ratio of 17.75:1. The age ranged from 8 to 65 years with a median age of 36.5 years.Maximum numbers of patients were found in age group of 21-30 and 41-50 with female preponderance in each group of thyroiditis. 75 csaes of thyroiditis have been evaluated on the basis of cytomorphological criteria and clinical findings of patients. All the patients had a history of goiter. 56 patient had diffuse swelling and 19 had nodular swelling. Out of 75 cases of thyroiditis, Hashimoto's thyroiditis 56(74.66\%), Lymphocytic thyroiditis 18(24\%), de Quervain's thyroiditis 1(1.33\%). 60 patients had estimation of thyroid profiles and thyroid antibodies.

Which will establish 10 euthyroidism, 2 hyperthyroidism and 48 hypothyroidism. The serum TPO antibody titers were elevated in 58 patients. 2 patients had normal titer. Biochemically hypothyroidism is more frequently evaluated with Hashimoto's disease. On the other hand, hyperthyroidism was observed in most other types of thyroiditis.

DISCUSSION: The present study shows that Hashimoto's thyroiditis is more common in the female population with female to male ratio of 17.75:1. ( Table1) Shirish S Chandanwale 
et al also reported a female male ratio of 16.33:1 in cases of Hashimoto's thyroiditis. ${ }^{6}$ The age group of patients who were diagnosed with Hashimoto's thyroiditis varied from 8 years to 65 years.

Only $74.66 \%$ presented with diffuse presentation. (Table2) Alka Bhatia et al 2007 also reported diffuse presentation in $89.47 \%$ of patients. ${ }^{7}$ Thyroid function tests were available in 60 patients and revealed that the majority of these patients were hypothyroid (80\%). (Table2) In the study done by Ekambaram $\mathrm{M}$ et al on 50 patients with Hashimoto's thyroiditis.

Thyroid profile was available for all 50 patients. In their study, $84 \%$ of patients were hypothyroid. ${ }^{8}$ Hypothyroidism in fairly large number of patients in our study is understandable due to an advanced stage of the disease at the time of diagnosis and represent destructive phase of the disease. Hashitoxicosis is a transient hyper thyroid phase of Hashimoto's thyroiditis. It is due to acute aggravation of thyroid autoimmunity induced destruction of thyroid follicles. Thyroid peroxidise antibodies (TPO Ab) were raised in 58 of patients and 2 had normal.

Clinical features and serum findings when used alone to diagnose Hashimoto's thyroiditis, diagnosis will be missed in many cases. ${ }^{9}$ The diagnosis can also be missed in smears with abundant colloid.

Aspiration from more than one site increased cellular yield and was useful for achieving correct diagnosis in our study. Similar observations were made by Hamburger. ${ }^{9}$ Hashimoto's thyroiditis, on FNAC smears, is diagnosed by oxiphilic (Hurthle) cell, infilteration of follicles by lymphocytes/plasma cells and the presence of moderate amount of colloid in the background. (Table3)FNAC is considered superior as well as more cost-effective in diagnosing Hashimoto's thyroiditis than antibody screening.8,10,11,12,13 Despite its superiority, FNAC has some pitfalls in diagnosing Hashimoto's thyroiditis. There is sometimes an overlap in the cytomorphological features of Hashimoto's thyroiditis and sub- acute lymphocytic thyroiditis

Hurthle cell change was seen in $80 \%$, which is higher than that seen in other studies. Monika Rathi et al and Friedman $\mathrm{M}$ et al also reported markedly high percentage of cases showing Hurthle cell change. ${ }^{14,15}$ Data in this study on follicular atypia $26.66 \%$ and follicular cell infilteration by lymphocytes $82.66 \%$ were comparable with the study of Jayaram et al. ${ }^{16}$

CONCLUSION: FNAC is a safe, reliable, cost effective and time saving method in the diagnosis of thyroiditis. Being a benign condition also reduce the rate of unnecessary operation, which can be treated conservatively. The study showed that there was no correlation between T4, T3, TSH measurements and FNA cytological diagnoses.

\section{REFERENCES:}

1. Amino N, Tada H, Hidaka Y. Chronic (Hashimoto's) thyroiditis. In: DeGroot LJ, Jameson JL, editors. Endocrinology. $4^{\text {th }}$ ed., Vol. 2. Philadelphia: Saunders Publication; 2001. P. 1471-80.

2. Kumar N, Ray C, Jain S. Aspiration cytology of Hashimoto's thyroiditis in an endemic area. Cytopathology. 2002;13:31-9.
3. Kocian G. Lymphoid infiltrates. $1^{\text {st }}$ ed. Fine needle aspiration cytology-diagnostic principles and dilemmas. In: Schroder G, editor. Germany: Springer; 2006. P.99-101.

4. Maewaha RK, Tandon N, Karak AK, Gupta N, Verma K, Kochupillai N. Hashimoto's thyroiditis: Countrywide screening of goitrous healthy young girls in postiodization phase in India. J Clin Endocrinol Metab. 2000; 85:3798-802.

5. Zois C, Stavrou I, Kalogera C, Svarna E, Dimoliatis I, Seferiadis $K$, et al. High prevalence of autoimmune thyroiditis in schoolchildren after elimination of iodine deficiency in northwestern Greece.

Thyroid. 2003; 13:485-9.

6. Shirish S Chandanwale, Charusheela R Gore, Sunita A Bamanikar, Nidhi Gupta, Kanika Gupta. Cytomorphologic spectrum of Hashimoto's thyroiditis and its clinical correlation: A retrospective study of 52 patients. CytoJournal. 2014,11:9.

7. Bhatia A, Rajwanshi A, Dash RJ, Mittal BR, Saxena AK. Lymphocytic thyroiditis: Is cytological grading significant? A correlation of grades with clinical, biochemical, ultrasonographic and radionuclide parameters. CytoJournal. 2007;4:10.

8. Ekambaram M, Kumar B, Chowdhary N, Siddaraju N, Kumar S. Significance of eosinophils in diagnosing Hashimoto's thyroiditis on fine needle aspiration cytology. Indian J Pathol Microbiol.2010;53:476-9.

9. Hamburger JI, Hamburger SW. Fine needle biopsy of thyroid nodules: Avoiding the pitfalls. N Y State J Med. 1986;86:241-9.

10. Orell SR, Sterrett GF, Darell W. Thyroid. In:Orell SR, Sterrett GF, Darell W, editors. Fine needle aspiration cytology. $4^{\text {th }}$ ed. India: Elsevier Science Ltd; 2005.p.136-8.

11. Jayaram G, Marwaha RK, Gupta RK, Sharma SK. Cytomorphological aspects of thyroiditis: A study of 51 cases with functional, immunologic and ultrasonographic data. Acta Cytol .1987;31:687-93.

12. Poropatich C, Marcus D, Oertel YC. Hashimoto's thyroiditis: Fine-needle aspirations of 50 asymptomatic cases. Diagn Cytopathol .1994;11:141-5.

13. Kumar N, Ray C, Jain S. Aspiration cytology of Hashimoto's thyroiditis in an endemic area. Cytopathology. 2002; 13:31-9.

14. Monika Rathi, Faiyaz Ahmad, Satish Kumar Budania, Seema Awasthi, Ashutosh Kumar and Shyamoli Dutta. Cytomorphological Aspects of Hashimoto's Thyroiditis: Our Experience at a Tertiary Center. Clinical Medicine Insights: Pathology.2014:7.

15. Friedman M, Shimaoka K, Rao U, Tsukada Y, Gavigan M, Tamura K. Diagnosis of chronic lymphocytic thyroiditis (nodular presentation) by needle aspiration. Acta Cytol. 1981;25:513-22.

16. Jayaram G, Iyengar KR, Sthaneshwar $P$, Hayati JN. Hashimoto's thyroiditis-A Malaysian perspective. J Cytol. 2007;24:119-24. 


\begin{tabular}{|c|c|c|c|c|c|c|}
\hline Age & Male & Female & $\begin{array}{c}\text { Hasimoto } \\
\text { Thyroiditis }\end{array}$ & $\begin{array}{c}\text { Lymphocytic } \\
\text { Thyroiditis }\end{array}$ & $\begin{array}{c}\text { de } \\
\text { Quervain's } \\
\text { Thyroiditis }\end{array}$ & \begin{tabular}{c} 
Total \\
\hline$<10$
\end{tabular} \\
\hline $10-20$ & 1 & 1 & 1 & 0 & 0 & 1 \\
\hline $21-30$ & 1 & 9 & 8 & 2 & 0 & 10 \\
\hline $31-40$ & 0 & 18 & 15 & 4 & 0 & 19 \\
\hline $41-50$ & 2 & 18 & 14 & 6 & 1 & 15 \\
\hline $51-60$ & 0 & 5 & 5 & 6 & 0 & 20 \\
\hline $61-70$ & 0 & 5 & 5 & 0 & 0 & 5 \\
\hline $71-80$ & 0 & 0 & 0 & 0 & 0 & 5 \\
\hline $81-90$ & 0 & 0 & 0 & 0 & 0 & 0 \\
\hline $91-100$ & 0 & 0 & 0 & 0 & 0 & 0 \\
\hline Total & $\mathbf{4 ( 5 . 3 3 \% )}$ & $\mathbf{7 1}(\mathbf{9 4 . 6 6 \% )}$ & $\mathbf{5 6}(\mathbf{7 4 . 6 6 \% )}$ & $\mathbf{1 8}(\mathbf{2 4 \% )}$ & $\mathbf{1}(\mathbf{1 . 3 3 \% )}$ & $\mathbf{7 5}$ \\
\hline \multicolumn{7}{|c|}{ Table1: Age distribution and type of Thyroiditis } \\
\hline
\end{tabular}

\begin{tabular}{|c|c|}
\hline Female:Male & $\mathbf{1 7 . 7 5 : 1}$ \\
\hline Age range & $8-65$ year \\
\hline Median age & 36.5 year \\
\hline Maximum age found & $21-30$ and $41-50$ \\
\hline Clinical feature & $19(25.33 \%)$ \\
\hline Nodular & $56(74.66 \%)$ \\
\hline Diffuse & $48(80 \%)$ \\
\hline Hormonal status (n=60) & $2(3.33 \%)$ \\
\hline Hypothyroid & $10(16.66 \%)$ \\
\hline Hyperthyroid & Euthyroid \\
\hline \multicolumn{2}{|c|}{ fable 2: Nature of thyroid swelling and Thyroid } \\
\hline
\end{tabular}

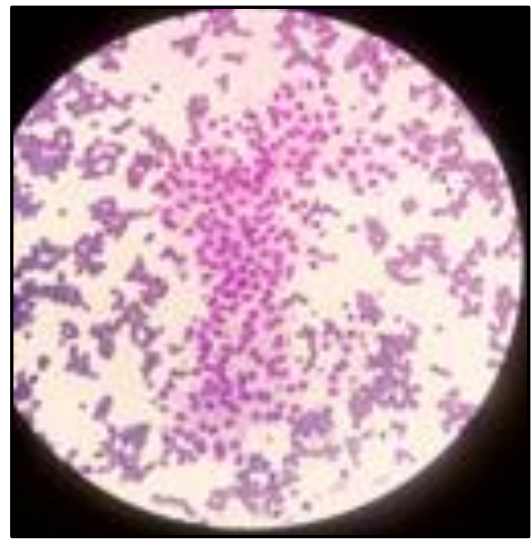

\begin{tabular}{|c|c|}
\hline Cytomorphologic features & No. of cases \\
\hline Increased background lymphocytes & 75 \\
\hline Lymphocytic infilteration of follicles & 62 \\
\hline Hurthle cell & 60 \\
\hline Anisonucleosis & 20 \\
\hline Giant cells & 1 \\
\hline Colloid & 5 \\
\hline Epitheloid cell & 57 \\
\hline Plasma cell & 0 \\
\hline Table 3: Frequency of all Cytomorphologic \\
features of 75 patient \\
\hline
\end{tabular}

Fig. 2: Thyroid follicular cell intermixed with lymphocytes

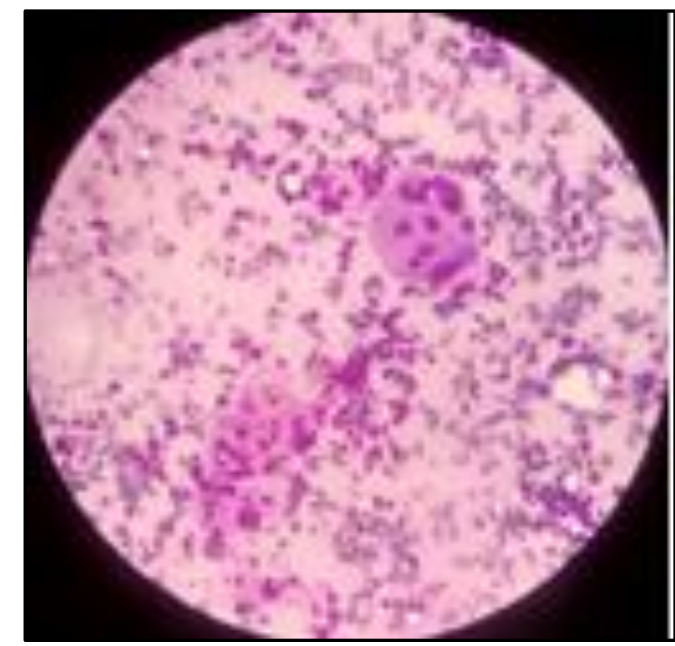

Fig. 1: Giant Cell

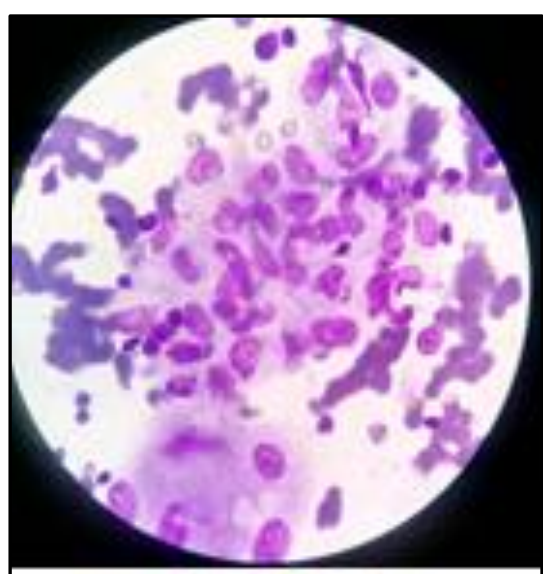

Fig. 3: Epithelioid Granuloma

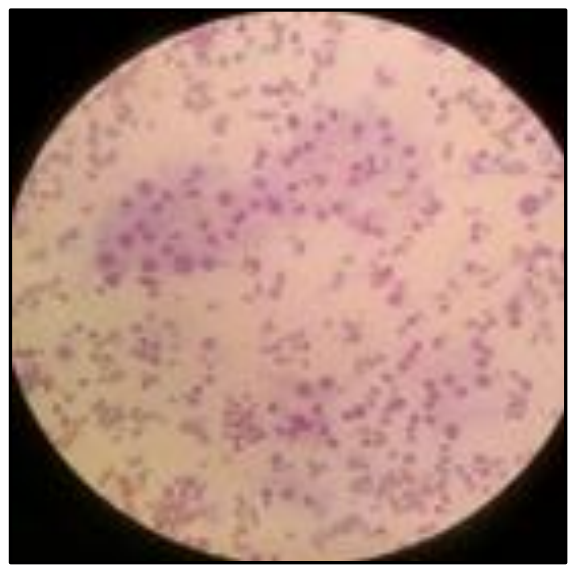

Fig. 4: Hurthle Cell 